\title{
The pull apart-type Tardets-Mauléon Basin, a key to understand the formation of the Pyrenees
}

\author{
Joseph Canérot ${ }^{*}$ \\ GET-OMP, Université Paul-Sabatier, 14 rue Ed. Belin, 31400 Toulouse, France
}

\begin{abstract}
Contrary to recent conceptual models, we evidence that the Mauléon Basin does not only result from the Pyrenean tectonic inversion of an aborted Albian rift involving a N-S extreme crust thinning, with related detachment and mantle exhumation. It actually corresponds to an element of this rift system where EW dominant regional sinistral strike slip faulting between its European and Iberian margins generated as early as the Latest Aptian (Clansayesian) an oblique pull apart-type basin: the Tardets-Sorholus Trough. Then, towards the Late to Latest Albian period, the active transverse, SW-NE oriented, Barlanès and Saison listric faults provided the main crustal thinning leading locally (Urdach) to mantle exhumation. Finally, at the beginning of the Late Cretaceous, the trough widened through transtension motion (N-S distension associated with E-W sinistral strike slip) leading to the creation of the Mauléon Basin. This geodynamic evolution gives to the Mauléon Basin its logical place between the western Bilbao Basin where oceanic crust developed through dominant N-S extension process and the central and eastern north Pyrenean basins where dominant $\mathrm{E}-\mathrm{W}$ left lateral strike slip then transpressive motion preclude mantle denudation. From the Late to Latest Cretaceous, the inverted motion turning to generalized regional transpression led to the closure of the trough, then, by gradual uplift from east to west, to the formation of the Pyrenean range.
\end{abstract}

Keywords: Tardets-Mauléon pull apart Basin / Cretaceous / European margin / Iberian margin / North Pyrenean Trough / Western Pyrenees

Résumé - Le bassin «pull apart » de Tardets-Mauléon, une clé pour comprendre la formation des Pyrénées. Contrairement aux modèles conceptuels récemment présentés, le bassin de Mauléon ne résulte pas de la simple inversion tectonique pyrénéenne d'un rift albien avorté impliquant un amincissement crustal N-S extrême, avec détachement et décoiffement mantellique. Il s'agit en réalité d'un élément de ce rift au sein duquel le décrochement régional W-E sénestre dominant entre ses marges européenne et ibérique a généré dès l'Aptien terminal (Clansayésien) un fossé oblique de type pull apart, le fossé de TardetsSorholus. C'est à la faveur des failles listriques transverses d'orientation SW-NE du Barlanès et du Saison, particulièrement actives, que s'est réalisé ensuite, à l'Albien supérieur-terminal, l'amincissement crustal majeur, pouvant conduire localement (Urdach) au décoiffement mantellique. Par la suite, au début du Crétacé supérieur, ce fossé s'est élargi par transtension (distension N-S associée à un décrochement sénestre $\mathrm{W}$-E) pour laisser place au bassin de Mauléon. Ainsi interprété, ce dernier bassin s'intègre logiquement au sein du rift composite crétacé nord-pyrénéen en prenant place entre le bassin de Bilbao à extension N-S dominante et croûte océanique bien développée, à l'ouest et les bassins plus orientaux des Pyrénées centrales et orientales où le mouvement décrochant sénestre W-E voire transpressif devient dominant, interdisant tout décoiffement mantellique. C'est l'inversion du mouvement et la généralisation de la transpression qui, à partir du Crétacé supérieur-terminal, conduiront à la fermeture de ce fossé puis à la surrection graduelle, cette fois d'est en ouest, de la chaîne pyrénéenne.

Mots clés : Basin pull apart de Tardets-Mauléon / Crétacé / marge européenne / marge ibérique / sillon nord-pyrénéen / Pyrénées occidentales

\footnotetext{
*Corresponding author: jcanerot@live.fr
} 


\section{Introduction}

The Pyrenees are generally interpreted as an interplate belt resulting from the collision between Europe and Iberia (Le Pichon et al., 1970; Le Pichon and Sibuet, 1971; Choukroune and Mattauer, 1978; Gong et al., 2008; Srivastava et al., 1990a, b; Olivet, 1996; Sibuet et al., 1971, 2004). This collision could have occurred through the Cenozoic inversion of an old rift opened during the Cretaceous period (Puigdefabregas and Souquet, 1986). Generating an extreme N-S crust thinning with detachment faulting, this opening could have led to the creation of oceanic crust (Stampfli, 2011; Vissers and Meijer, 2012), and even to a wide exhumation of the peridotitic upper mantle (Lagabrielle and Bodinier, 2008; Jammes, 2009; Jammes et al., 2009; Lagabrielle et al., 2010; Masini, 2011; Clerc et al., 2012; Masini et al., 2012; Corre et al., 2016; Teixell et al., 2016; Saint-Blanquat et al., 2016). The considered studies commonly suggest that the Mauléon, Baronnies, Ballongue, Aulus and Saint-Paul de FenouilletBoucheville basins (for location, see Fig. 1) characterize this tectonic evolution.

Our works carried out on those basins are not in agreement with these geodynamic models which, in our opinion, do not fit field evidences. Indeed, in the Tardets-Mauléon Basin we have recently evidenced (Debroas et al., 2010) that the local (Urdach) mantle denudation is not directly connected with an hypothetical E-W, weakly north dipping, detachment related to $\mathrm{N}-\mathrm{S}$ distension but in fact with a transverse, NE-SW oriented, fault zone (the Barlanès fault) activated by a W-E sinistral strike slip regional motion. In the same way, we have demonstrated (Debroas et al., 2013) that in the more eastern Baronnies, Ballongue and Aulus basins (Fig. 1) the outcropping of the peridotites (commonly lherzolites) is not associated with a mid-Cretaceous extreme crustal thinning inducing a north-dipping detachment with mantle denudation but to the Pyrenean compression, Late Cretaceous to Tertiary in age and to the subsequent erosion process.

The observations reported hereafter evidence that the Tardets-Mauléon Basin (Fig. 2) provides the best constraints for a suitable understanding of the structural and geodynamic evolution of this part of the North Pyrenean Zone. They strengthen a previous model presented for the Central Pyrenees (Debroas and Souquet, 1976; Debroas, 1985, 1987, 1990, 2003, 2013; Debroas et al., 2013) and lead us to propose a new interpretation for the formation process of this Cretaceous basin and its incorporation into the Cenozoic belt.

\section{The privileged situation of the Tardets- Mauleon Basin}

Located in the western part of the French Pyrenees (Figs. 1 and 2), the Tardets-Mauléon Basin provides valuable informations on various topics illustrated in the regional mapping (Castéras, 1970, 1971; Le Pochat et al., 1976, 1978). The sedimentary infilling is well preserved: the Palaeozoic basement is covered by various formations ranging from the Permo-Triassic up to the Eocene (Fig. 3). This post-Hercynian cover involves thick and well-dated series especially in the Cretaceous characterized by a $4000 \mathrm{~m}$ thick unit of Albian "Flysch Noir" deposited during the formation of the basin
(Souquet et al., 1985). The Pyrenean compression amount (near $80 \mathrm{~km})$ (Teixell, 1998) is weak in this western part, compared to the eastern part of the belt (more than $150 \mathrm{~km}$ ) (Muñoz, 1992; Canérot et al., 2012). Finally, the erosion remains moderated, specially near the southern Axial Zone (High Primary Range). The Pyrenean structures are either folded or unfolded, allowing a good access to the previous location and geometries of the Early Cretaceous morphologies closely related to the formation of the basin. These structures also provide a suitable appreciation of their influence during the Late Cretaceous and Tertiary evolution of the basin and its following integration within the Pyrenean belt. Finally, some seismic profiles and oil drillings provide important complementary data specially on the northern side of the area, close to the Arzacq basin (Flament, 1985; Serrano et al., 2006).

\section{Formation and evolution of the Mauleon Basin during the cretaceous}

Three main successive stages can be selected within this Mesozoic interval (Souquet et al., 1985; Debroas et al., 2010; Canérot et al., 2012).

\subsection{Latest Aptian (Clansayesian)-Early Albian: break down of the Urgonian platform}

Regionally developed during the Gargasian (Middle Aptian) period, this Urgonian-type platform was suddenly broken down into a mosaic involving several pluri-kilometrescale moving crustal blocks (Canérot and Delavaux, 1986). The movements of these different units are still difficult to decipher in the center of the basin where a thick flysch infilling covers the Aptian carbonates. On the contrary, these units can be more easily appreciated along the southern border of the basin where the platform is widely outcropping. So, the Mail Arrouy block (A, Fig. 4) shows a clear tilting movement towards the ENE, leading to the development of a sedimentary system including from west to east, the Mail Arrouy rudistbearing carbonate platform, the Arudy slope-bearing mudmounds and the Sainte-Colome basin filled up with spiculebearing black marls (Debroas et al., 2010; Canérot et al., 2012). Although moderated, the same general movement is observed along the southern Sarrance block (B, Fig. 4). On the contrary, the western Lichençumendy unit shows a tilting movement towards the NW (C, Fig. 4) with a sedimentary polarity illustrated by the SE-NW migration of the Uppermost Aptian (Clansayesian) coral reefs (B in plate 1). Farther west, the Arbailles block (D, Fig. 4) shows an ESE tilting characterized mainly by the development of the Beloscare diapir and its ring syncline whose bottom beds show gravity boulders which slid down from the surrounding carbonate platform (Canérot, 2008) (A in plate 1).

Following the proposed model, this first step is indeed characterized by the regional diapirism of the Triassic evaporites. The most significant examples beyond the Beloscare diapir are the Lauriolle (C in plate 1), Sarrance, Lichançumendy, Hosta, Iholdy examples and above all the Roquiague composite structure (diapiric complex Saison zone), located close to the center of the younger TardetsSorholus Trough (see below). These structures pointed out on 


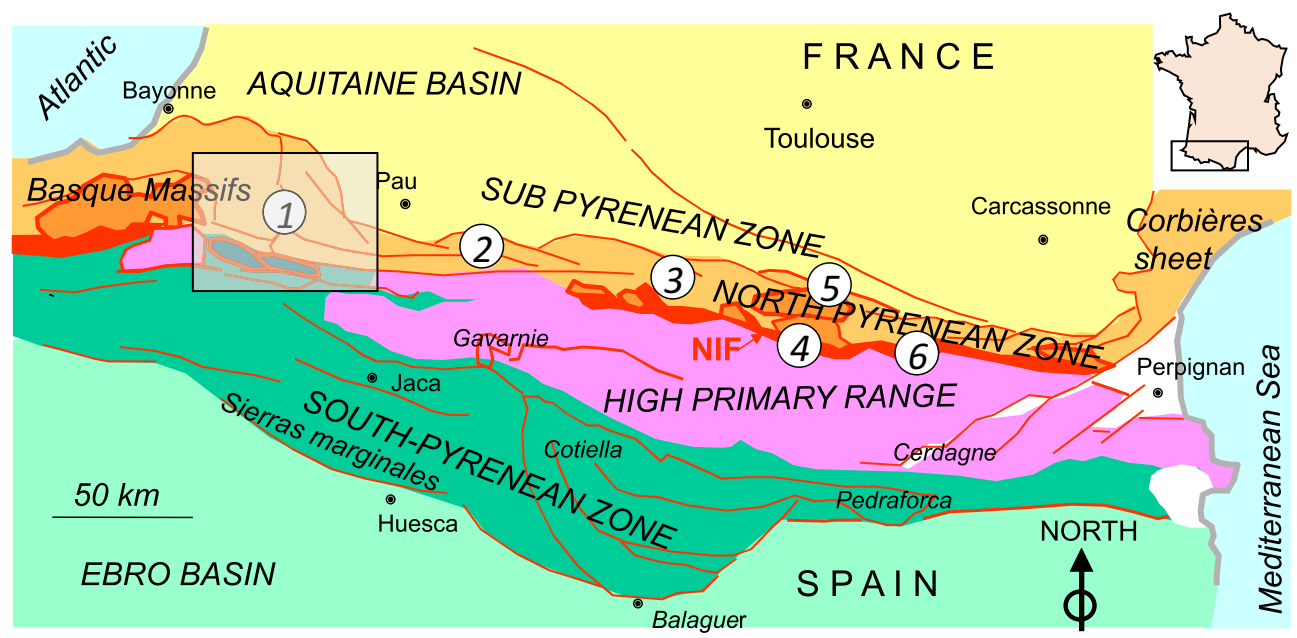

Fig. 1. Structural map of the Pyrenees (from J. Canérot, 2008) showing the location of the Tardets-Mauléon (1), Lourdes-Baronnies (2), Ballongue (3), Aulus (4), Camarade (5) and Saint-Paul de Fenouillet-Boucheville (6) Cretaceous flysch basins.

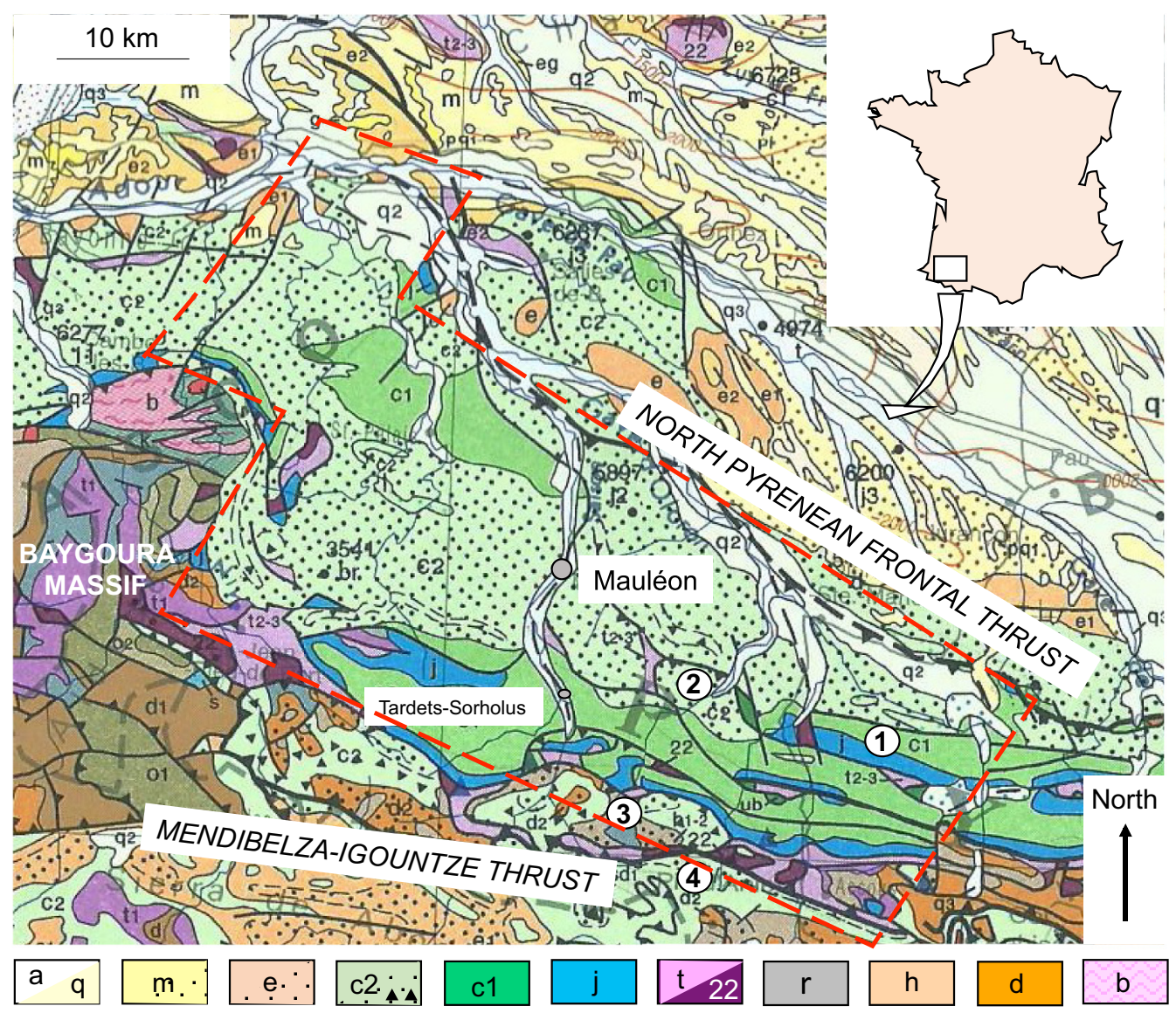

Fig. 2. Geological map of the Mauléon Basin and surrounding area (from Carte géologique de la France à $1 / 1000$ 000, 6 édition - 1996, BRGM Ed.). 1 to 4: selected stratigraphic sections in Fig. 3. Red doted line corresponds to Diagram D in Fig. 6. a: Quaternary alluvial deposits; q: PlioQuaternary colluvium; m: Miocene; e: Eocene; c2: Upper Cretaceous; c1: Early Cretaceous; j: Jurassic; t: Triassic and ophites (22); r: Permian; h: Carboniferous; d: Devonian; b: Cambro-Ordovician.

Fig. 6A, developed at the crossing of faults oriented W-E and SW-NE, respectively. We know that the sinistral strike-slip movement along the first main W-E fault zones generated extension along the transverse following ones (Canérot, 1988; James and Canérot, 1999; Canérot, 2008).

\subsection{Midlle to Late Albian-Early Cenomanian: formation of the Tardets-Sorholus Trough}

Crustal block-tilting started by the end of the Aptian (Clansayesian) and increased during the Albian period, 


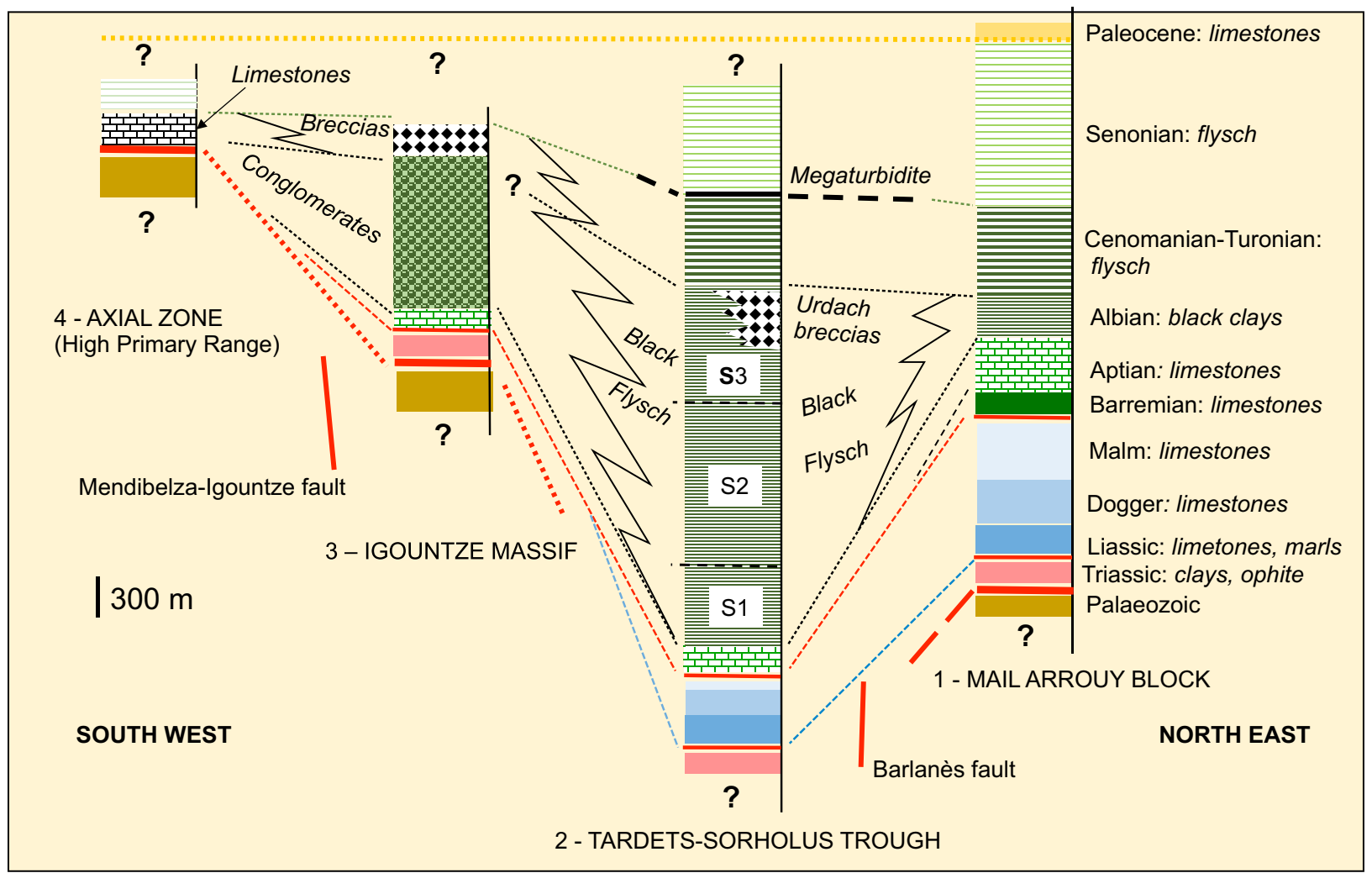

Fig. 3. Compared lithostratigraphic columns showing the Mesozoic filling evolution of the Tardets-Mauléon Basin

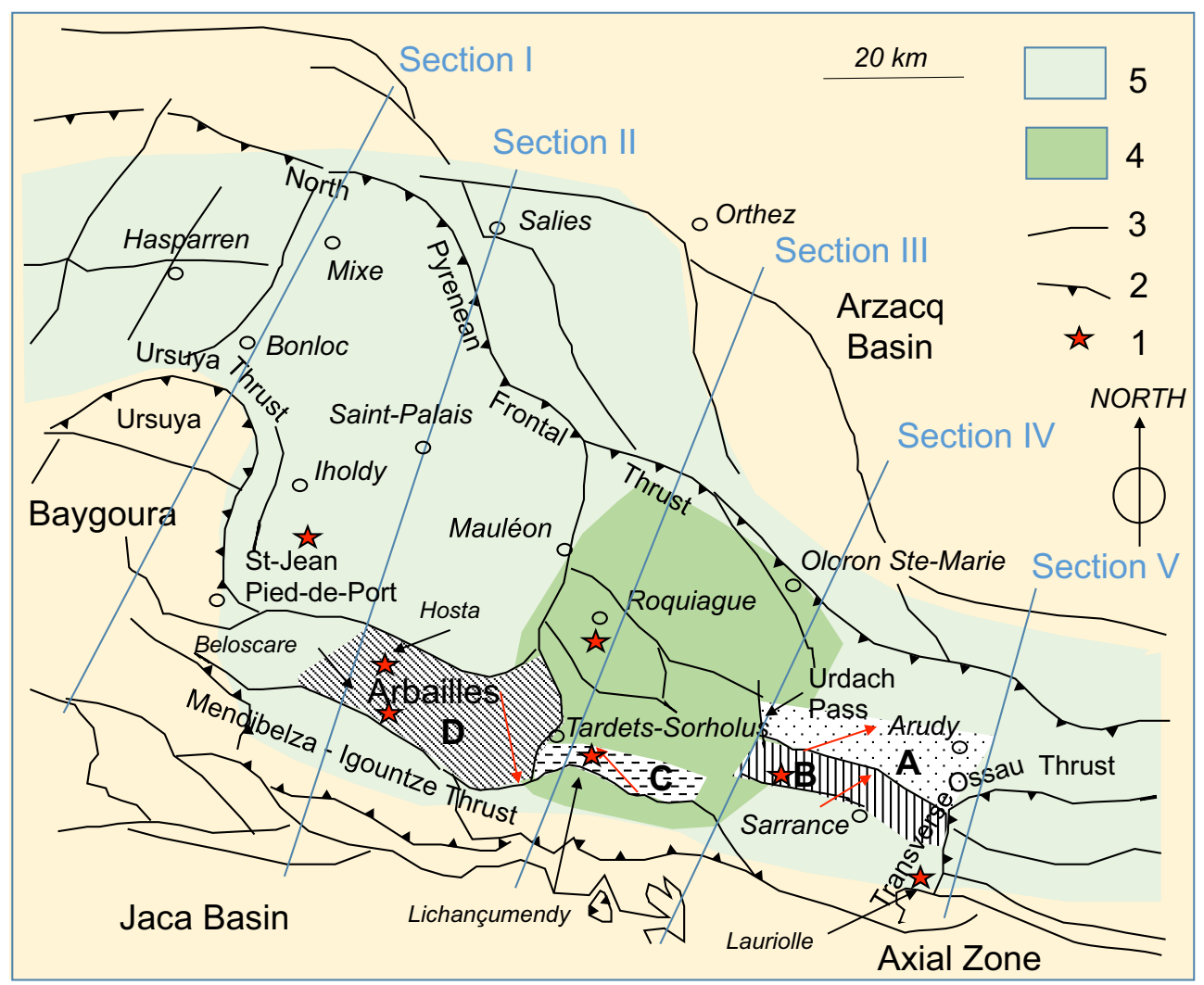

Fig. 4. Structural diagram of the Tardets-Mauléon Basin. I à V: Cross sections (see Fig. 10); A: Mail Arrouy Block; B: Sarrance Block; C: Lichançumendy Block; D: Arbailles Block; 1: main diapiric structures; 2: main thrusts; 3: important faults; 4: Tardets-Sorholus Flysch Trough; 5: Mauléon Basin. Red arrows indicate the block tilting direction. 

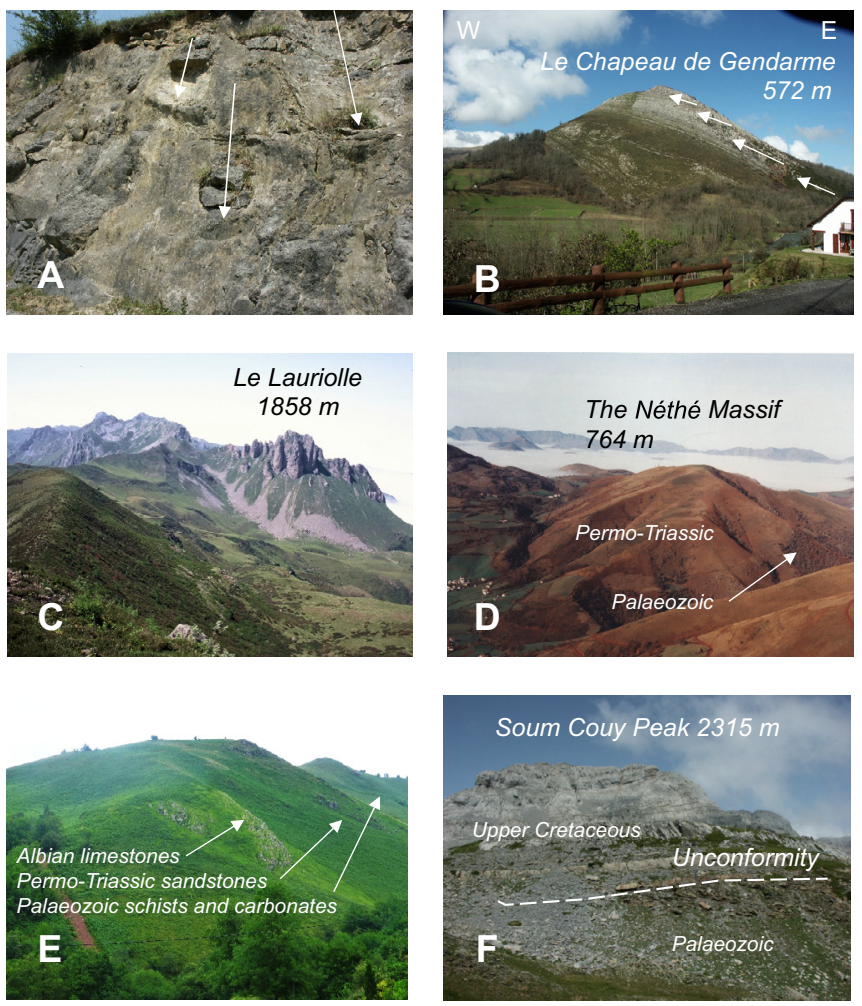

Plate 1. A Clansayesian (Uppermost Aptian) slumped reef boulders in the Arbailles block. Arrows indicate the southward (bottom) slumping direction; B: Westward prograding Clansayesian reefs (arrows) in the Lichançumendy block; C: The Lauriolle massif made up of Early Cretaceous diapiric breccias; D: The Néthé Massif made up of Palaeozoic and Permo-Triassic sediments in the northern part of the Arbailles block; E: The Igountze Massif showing here a Palaeozoic bedrock and its cover made up of Permo-Triassic sandstones and Cretaceous (Clansayesian-Lower Albian) limestones. F: In the southern part of the Mauléon Basin (Axial Zone=High Primary Range) the Upper Cretaceous limestones overlie unconformably the Palaeozoic schists.

especially along the Mail Arrouy unit. At the tip of the block (Soum de Segu and Bellevue peak see Fig. 5) the Albian series is absent and the Cenomanian carbonate blue flysch overlaps westward the Urgo-Aptian limestones and the Lower Albian spicule marls, covering directly the Upper then the Middle Jurassic limestones (Fig. 5). Westward of Urdach Pass, the eroded Mail Arrouy block gives suddenly place to the TardetsSorholus subsiding trough (Fig. 6B). The "Flysch Noir" infilling of this narrow basin was limited by active normal faults whose important throw allowed the deposition of more than $4000 \mathrm{~m}$ of flysch sediments (section 2 in Fig. 3). The infilling is organized into 3 main successive sequences (Souquet et al., 1985) dated from the Middle Albian (S1), the Upper Albian (S2) and the Vraconian-Lower Cenomanian (S3) respectively. The last one includes the famous Urdach Breccias reworking the mantle peridotites (lherzolites), the Palaeozoic stretched basement and different lithologies of its deeply eroded Mesozoic cover (Fig. 5) (Debroas et al., 2010; Canérot et al., 2012).

In the proposed interpretation, the last sequence S3 leads to local mantle exhumation with deposition of polygenic breccias reworking the Urdach lherzolites at the top of the Albian flysch (Fig. 8B). The recent models involving this denudation commonly consider that the process could be regional, multi decakilometre-scale and closely related to one or several detachment faults shallowly dipping towards the north (Jammes, 2009; Masini, 2011; Masini et al., 2012; Corre et al., 2016; Teixell. et al., 2016). In some of these models, the Chaînons Bearnais units are interpreted as crustal rafts consisting of Jurassic and Early Cretaceous materials floating on the widely rising up mantle peridotites through a large sole of Triassic evaporites. Their northward sliding could even lead locally (Arbailles) to the formation of gravity folds and carry local chips of Palaeozoic crust (Lagabrielle et al., 2010).

Our field observations are not in agreement with these recent interpretations. Indeed, we have never observed such floating rafts nor the large E-W oriented and north dipping detachment faults allowing a mantle exhumation at a regional scale. This is particularly true for the Basque Arbailles Massif where the Triassic, Jurassic and Lower Cretaceous cover overlaps unconformably a thick (more than $400 \mathrm{~m}$ ) outcropping basement sequence consisting of Permo-Triassic sandstones and Carboniferous flysch (Culm) (D in plate 1) (Canérot, 2008). The basement rocks also occur in the Aspe and Ossau units where the peridotites are nevertheless outcropping in several points (Fig. 6B) such as Urdach, Sarraillé and Bénou.

In our opinion, the exhumation of the Urdach lherzolitic mantle is closely related to the escarpment of the transverse NE-SW oriented Barlanès fault (Figs. 5, 6B, 7 and 8) which, at the end of the Albian period, separated the top of the eastern tilted Mail Arrouy block from the western strongly subsiding Tardets-Sorholus basin (Debroas et al., 2010; Canérot et al., 2012). The pluri-kilometre-scale complex scarp corresponds to a listric fault zone whose heave is dipping to the WNW. The Barlanès fault zone strikes towards the SW, from Urdach pass to Arette area, running westward of Sarrance block (Fig. 4). Parallel to this fault zone, the active Saison fault bounds the Tardets-Sorholus basin westward (Figs. 6B, 7 and 8). This very complex transverse fault zone is responsible for the high diapiric activity observed in the Roquiague area (Figs. 8 and 10 , section III). It shows a strong throw and a heave dipping to the ESE, which allowed the deposition of several kilometers of black flysch. The opposite normal displacement of these transverse, parallel, SW-NE oriented, Saison and Barlanès fault zones, is closely related to a strong W-E sinistral strike slip motion along the bordering fault zones which bound the Tardets-Sorholus basin to the north in the Saint-Palais area (part of the future North Pyrenean Frontal Thrust) and to the south, along the Mendibelza and Igountze massifs (Fig. 6). During this period, the lateral Bearnese and Basque areas correspond to raised shoulders with weakly thinned crust, subsequently involved in the rifting process leading to the formation of the Mauléon Basin (Figs. 6C and 7).

During this period, the crustal Tardets-Sorholus tear zone widened also towards the NW (Mixe) and particularly towards the south, involving active bordering faults. In the last area, normal (north dipping) and synchronous W-E left lateral faulting allowed the deposition of the famous Mendibelza conglomerates (section 3 in Fig. 3) (Boirie, 1981; Boirie and Souquet, 1982). This detrital formation involves deltaic to marine slope deposits which overlap unconformably a bedrock 

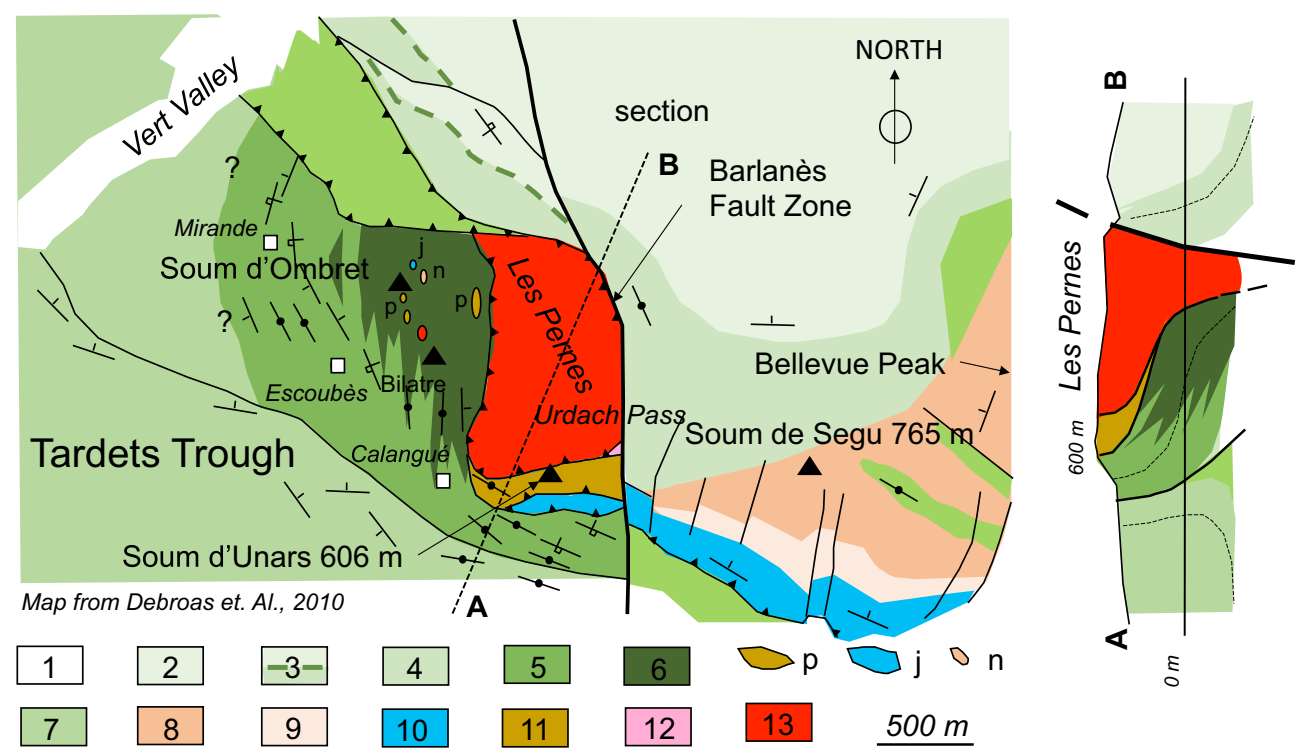

Fig. 5. Geological map and section of the Col d'Urdach area. Note the structural position of the lherzolite slice within the Cretaceous flysch and Urdach breccias. 1: alluvial deposits; 2: Lower Senonian flysch; 3: Osquich Pass megaturbidite (Turono-Coniacian boundary); 4: Upper Cenomanian and Turonian carbonate flysch; 5: Vraconian-Early Cenomanian Flysch Noir; 6: Olistolite-bearing Urdach breccias (p: Palaeozoic; J: Jurassic; n: Early Cretaceous); 7: Early Albian black marls; 8: Upper Aptian limestones; 9: Lower Aptian marls; 10: Barremian and Jurassic limestones; 11: Palaeozoic; 12: gneiss; 13: lherzolite.

consisting of a Palaeozoic (Devonian and Carboniferous) basement and its Mesozoic cover made up of Permo-Triassic (conglomerates, sandstones and siltstones) and Cretaceous (Uppermost Aptian to Albian limestones) units (E in plate 1 and section 3 in Fig. 3). In some places, they involve olistolites of the same Palaeozoic and Mesozoic formations (Canérot, 2008). Towards the north, the Mendibelza conglomerates interfinger with black sandy flysch indicating open marine sedimentary conditions towards the Tardets-Sorholus basin. It is worthy to note that the conglomeratic formations are closely related to the Tardets trough, underlining the limited extension of this sedimentary basin during the Albian to Early Cenomanian period.

\subsection{Middle Cenomanian to Turonian: formation of the Mauléon Basin}

After the Middle Cenomanian time, the persistent regional sinistral W-E strike slip faulting and the accelerated N-S extension led to a dramatic widening of the Tardets-Sorholus Albian trough, extending north towards the Aquitaine platform and south, towards de Pyrenean High Range. In the last domain, the southern blocks of the Igountze and Mendibelza Massifs were broken down and the onlapping Mendibelza conglomerates reworked the newly deposited Cenomanian carbonate platform (Prealveolina-bearing limestones). This widening operated also eastward, towards the "Chaînons Béarnais", sinking an old Albian shoulder and westward, involving the Baygoura-Ursuya basque massif. New transverse normal, SW-NE oriented faults, were activated such as the Ossau and Saint-Jean-Pied-de-Port faults (Figs. 6C and 7) which participated to the formation of the new Mauléon Basin. Their vertical throw is nevertheless weak, compared to the Barlanès and Saison ones, and the crust thinning was never able to lead to mantle exhumation.
Through its location and extension, the Turono-Coniacian Osquich Pass megaturbidite perfectly highlights the palaeotopography of this newly widened basin. Slipping down northward from the southern Cretaceous platform located on the present Axial Zone (High Range), it indeed overlaps westward the old southern border of the Tardets-Sorholus Trough covered by the Mendibelza conglomerates and crosses the Baygoura massif to reach the Basque Coast in the Upper Cretaceous Saint-Jean-de-Luz basin. On the contrary, this turbiditic body disappears suddenly eastward, close to the Urdach Pass (Figs. 3, 5 and 8C), just above the old transverse Barlanès fault zone.

This tectonic evolution continued during the Late Cretaceous, up to the Campanian, leading to the integration of the Mauléon Basin within the west Pyrenean marine domain (F in plate 1) (Ternet, 1965; Razin, 1989; Claude, 1990), widely opened westward towards the present Gulf of Biscay. But the W-E left lateral strike slip motion and the N-S extension decreased, moving gradually to the Pyrenean compression period.

\section{Place of the Mauleon Basin within the North Pyrenean cretaceous trough}

We have seen above that the Mauléon Basin arised from the Late Cretaceous widening of the Albian pull apart-type Tardets-Sorholus Trough. According to different previous studies (Debroas and Souquet, 1976; Souquet et al., 1985), this evolution process shows clearly two coexisting and complementary structural directions: N-S extension and E-W sinistral strike slip. This basin is different from the western Bilbao one where dominant N-S Albo-Cenomanian distension led to the creation of oceanic crust in the Gulf of Biscay (Montadert and Winnock, 1971; Boillot, 1984; Barbier et al., 1986; Bois et al., 

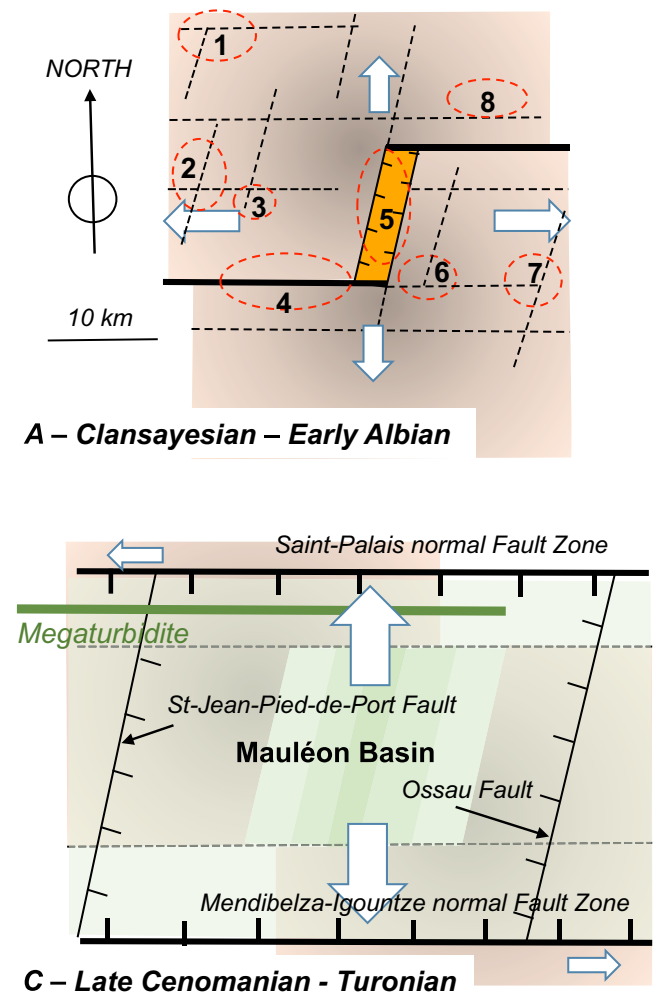
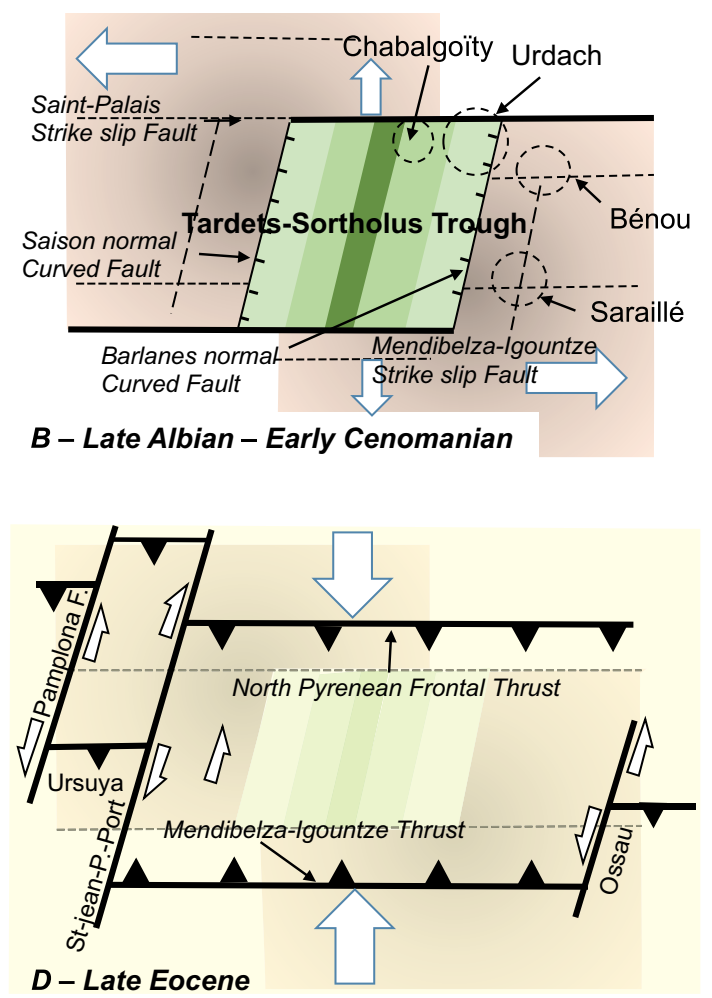

Fig. 6. Geodynamic evolution steps of the Mauléon Basin. A: Clansayesian (Uppermost Aptian)-Lower Albian: fracturing of the urgonian platform and major break down along the future Tardets Trough (orange color); starting of the West-Pyrenean diapiric process (1: Salies-deBéarn; 2: Iholdy; 3: Arhansus; 4: Béloscare; 5: Saison complex; 6: Sarrance; 7: Lauriolle; 8: Lasseube). B : Upper Albian -Lower Cenomanian: creation of the Tardets-Sorholus Trough through W-E main counterclockwise strike slip inducing local extreme crust thinning and low N-S distension. Note the location of the transverse Saison and Barlanès listric faults and the present Chabalgoïty, Urdach, Bénou and Sarraillé outcropping mantle peridotites (black circles). C: Upper Cenomanian-Turonian: creation of the Mauléon Basin through widening of the Tardets-Sorholus Trough with dominant N-S extension and associated counterclockwise W-E strike slip weak motion. The sedimentary area increases laterally, both westward, beyond the Saint-Jean-Pied-de-Port fault to the Saint-Jean-de-Luz Basin and eastward, beyond the Ossau fault zone, to the eastern Bearn Basin. Note the development of the Turono-Coniacian Osquich Pass megaturbidite westward of the old Barlanès fault zone. D: Upper Eocene: Development through N-S compression of the pyrenean structures within the Mauléon Basin. The old Upper Cretaceous normal faults are reworked into E-W thrust faults (south verging in the southern Mendibelza-Igountze massifs and north verging in the northern North Pyrenean Frontal Thrust) and the old SW-NE transverse faults into dextral or anticlockwise strike slip faults. Note the strong northward offsetting of the Baygoura-Ursuya Massif along the transverse Pamplona Fault Zone.

1997; Pedreira et al., 2007; Ferrer et al., 2008; Tugend et al., 2014). The change in the regional stress organization occurred probably close to the transverse intermediary Pamplona fault zone (Figs 6D and 7) (Razin, 1989; Claude, 1990).

Farther east, the North Pyrenean Cretaceous Flysch complex is represented by different small en échelon basins such as the Lourdes, Arrodets-Barousse, Baronnies, Ballongue, Salies-Camarade, Aulus, Nalzen and Pays de Sault ones (Fig. 9). The later Pyrenean compressive history does not allow any detailed reconstruction of the geometry of these Cretaceous basins. Nevertheless, contrary to the proposition made by the recent genetic models (Lagabrielle and Bodinier, 2008; Lagabrielle et al., 2010; Clerc et al., 2012; Lagabrielle et al., 2016), the Albian extension did not lead to mantle exhumation. This way, the breccias from the Aulus basin are not marine nor interbedded at the base of the Albian flysch infilling. Following the classical interpretation
(Colchen et al., 1997; Debroas, 2003, 2013; Canérot, 2008; Debroas and Azambre, 2012; Debroas et al., 2013), they correspond to:

- cataclasites generated within the distended crust, probably during the Early to Middle Cretaceous period, at the contact between the buried peridotite massif and the surrounding mesozoic formations;

- collapse breccias related to the Cretaceous Col d'Agnes diapir;

- continental, karst originated breccias (Coumettes Breccias), Latest Cretaceous and Tertiary in age, which rework both lherzolites and mesozoic carbonates newly exhumed by the Pyrenean compression.

So, according to this interpretation, all the above mentioned small sized eastern cretaceous basins could be 


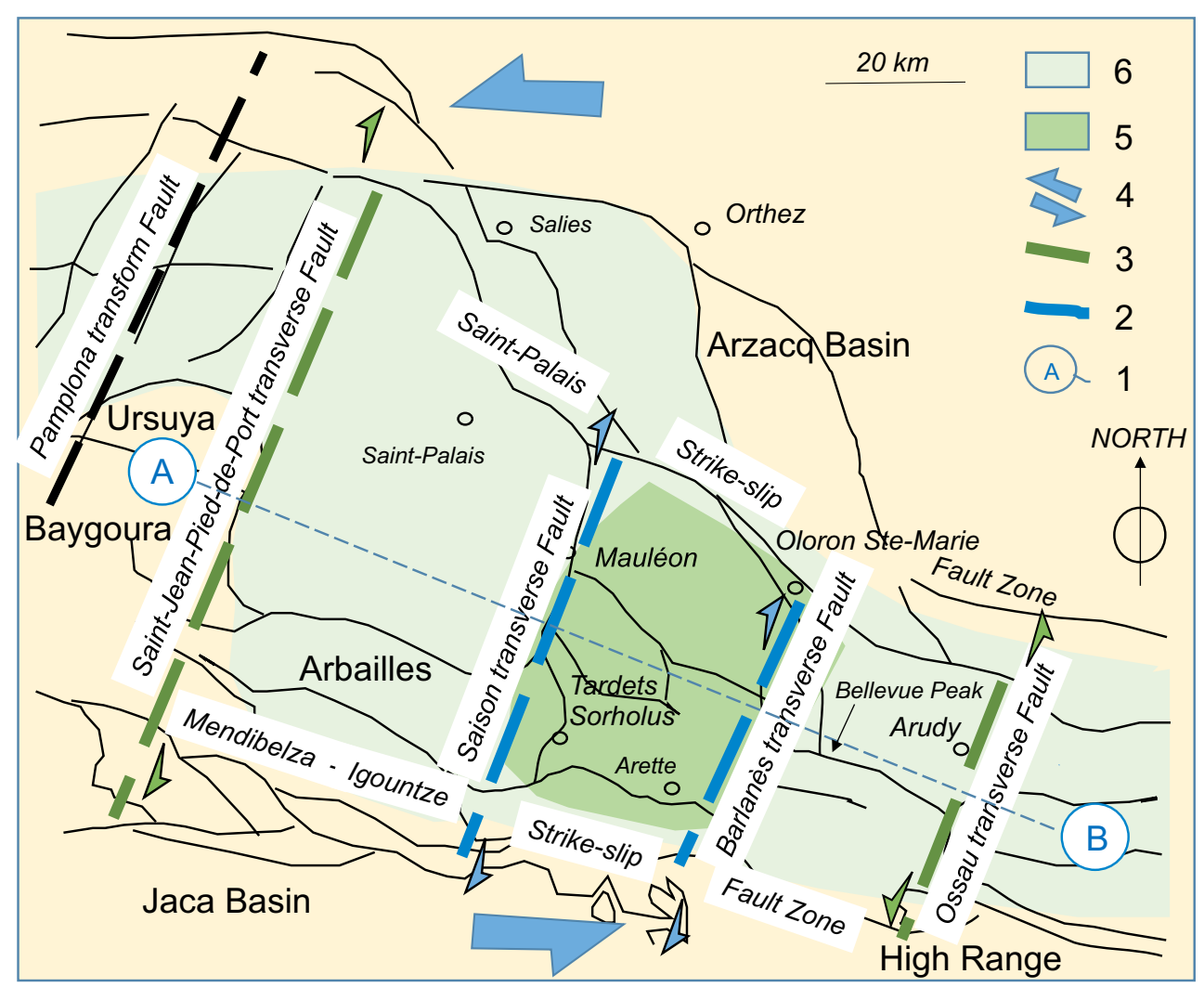

Fig. 7. Chronology of the transverse Cretaceous deformation steps within the Tardets-Mauléon Basin. The Albo-Aptian Saison and Barlanès Fault Zones are poorly represented, on account of the thickness of the flysch cover and the weakness of the pyrenean folding. On the contrary, the transverse Albo-Cenomanian bordering Ossau and Saint-Jean-Pied-de-Port faults are more obvious as they allow the outcropping of the Palaeozoic basement. 1: location of the cross sections (Fig. 8); 2: main Albo-Aptian fault zones; 3: main Albo-Cenomanian fault zones; 4: main Pyrenean faults; 5: Tardets-Sorholus Flysch Trough; 6: Mauléon-Saint-Jean-de-Luz Basin.

integrated within a geodynamic zone suffering a dominant genetic W-E sinistral strike slip motion (Debroas and Souquet, 1976, Azambre et al., 1991, Debroas, 1985, 1987, 1990, 2003). The upper mantle exhumation related to a supposed N-S Cretaceous extreme crust thinning inducing strong detachment north dipping faults is not demonstrated in any case. In our opinion, the North Pyrenean trough has been created through a regional W-E scissor-like Cretaceous movement running from the western Bilbao basin characterized by N-S dominant extension (see above) to the central and eastern Pyrenees small en échelon troughs where the dominant W-E strike slip motion prevented any exhumation of the lherzolitic mantle (Fig. 9). The Mauléon Basin which is located in an intermediate position combines both extension and strike slip movements and therefore represents a privileged central situation between these two extreme tecto-sedimentary arrangements.

\section{Compression and integration of the Tardets-Mauleon Basin within the Pyrenees}

\subsection{Regional framework}

We know that the Pyrenees have been generated within the European plate by a northward motion of the African plate. They do not correspond to a true collision belt between Europe and Iberia considering that Iberia, far from being an isolated tectonic plate, is really part of the European plate (Canérot, 2016). The regional N-S compression affected first the thinned crust separating the European margin of the Cretaceous NorthPyrenean flysch basin from its Iberian counterpart. This process began during the Late Cretaceous time (Upper Santonian?) in the eastern part of the belt then moved westward with a scissor-like closing motion during the Latest Cretaceous and Eocene times (Souquet et al., 1977; Canérot, 2008, 2016).

From a general point of view, the facing of the margins induced the reactivation of the old normal and wrench faults bordering the Cretaceous flysch trough into reverse or thrust faults. Pushed by the African plate, the Iberian crust suffered deep tectonic splitting before underthrusting gradually northward, under the European crust which, in response, has been divided into several superficial northward overlapping slices. The narrow facing suture zone offering subvertical structures with an important Moho jump between the thickened Iberian crust and the thinned European one has been recently named the "North Iberian Fault Zone" (Canérot, 2008, 2016). In the Eastern and Central Pyrenees, the N-S Tertiary compression amount is very high, close to $160 \mathrm{~km}$ after Muñoz (1992) and Verges et al. (1995), forbidding the precise reconstruction of the old Mesozoic fault and fold structures. 


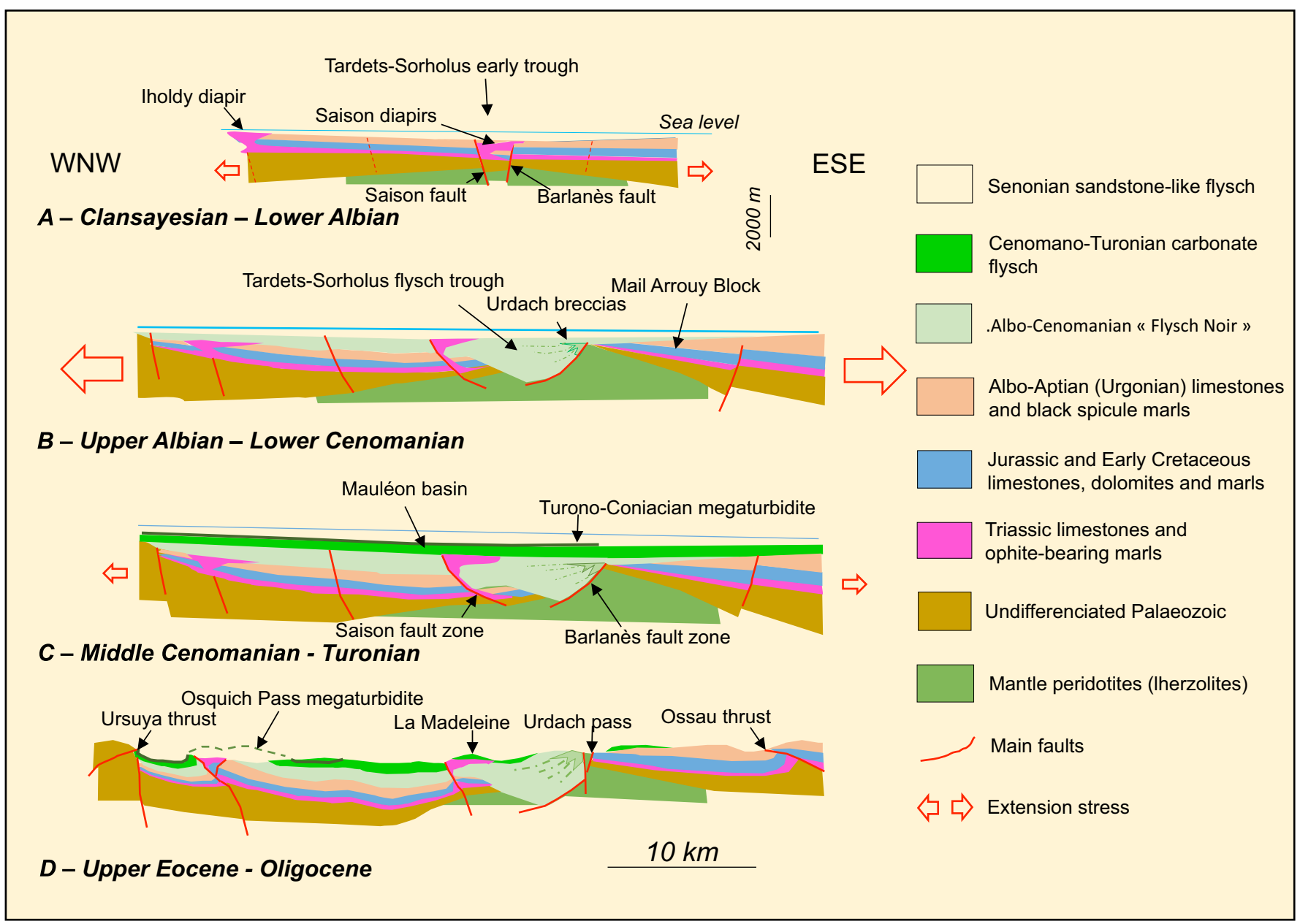

Fig. 8. Palinspastic WNW - ESE sections in the Tardets-Mauléon Basin. The crustal thinning related to the dominant W-E counterclockwise strike slip motion is very important during the Upper-Albian-Lower Cenomanian period. Note the location of the Turono-Coniacian Osquich Pass megaturbidite westward of the transverse Barlanès fault zone (sections $\mathrm{C}$ and $\mathrm{D}$ ).

\subsection{Tardets-Mauléon Basin}

In the Western Pyrenees, the Cenozoic compression is less important, close to $80 \mathrm{~km}$ after Teixell (1998) allowing a satisfactory reconstruction of the Cretaceous inherited structures. Indeed, within the Tardets-Mauléon Basin, three main different fold and fault generations can be distinguished.

\subsubsection{The W-E oriented strike folds and thrust faults}

The W-E oriented structures correspond mainly to the inverted Cretaceous normal faults (Figs. 6D and 10). This relationship is obvious in the Béarn (Bergon, OurdinseLayens, Sarrance) and Basque (Lichançumendy, Arbailles, Igountze, Mendibelza) mountains. Their geometry and general organisation evidence, as in the central Pyrenees, the continental subduction of the Iberian crust under the European one which, here in the Western Pyrenees, occurred near the beginning of the Tertiary period. Their recent interpretation (Dumont et al., 2015) as a result of a southward oriented thrust D1 is not observed. The European crust is in fact involved in a regional northern check structure and the considered southward thrust folds and imbrications observed in the "Chaînons Béarnais" zone, within the Iberian crust, correspond actually to a superficial response to the northward underthrust of southern units. Therefore, within the Pyrenean domain, contrary to the Dumont et al.'s suggestion (2015), the retroforeland Basin does not correspond to Aquitaine but to the Ebro Basin.

To the north of the Mail Arrouy unit, the subsurface data given by oil drillings and seismic profiles indicate a general north verging structural tendency (Flament, 1985; Serrano et al., 2006; Teixell et al., 2016). Following this interpretation, the axial part of the fan-shaped Pyrenean cross sections providing vertical structures is located close to the center of the Cretaceous Tardets-Sorholus Trough (Fig. 10). It develops eastward towards the Bénou Plateau and westward towards the Hasparren area, emphasizing the influence of the Mesozoic crust thinning on the following Pyrenean fold and fault structures. Therefore, this geodynamic interpretation differs from those considering that the diverging zone between Europe and Iberia must be located within the Iberian margin of the Tardets-Mauléon trough, more precisely within the Bedous small basin (Choukroune and Mattauer, 1978; Dumont et al., 2015). These authors aim to draw in this area the limit between the North Pyrenean Zone and the Axial Zone (Central High Range), i.e., the North Pyrenean transform fault which would separate the European and Iberian plates. But we know that in 


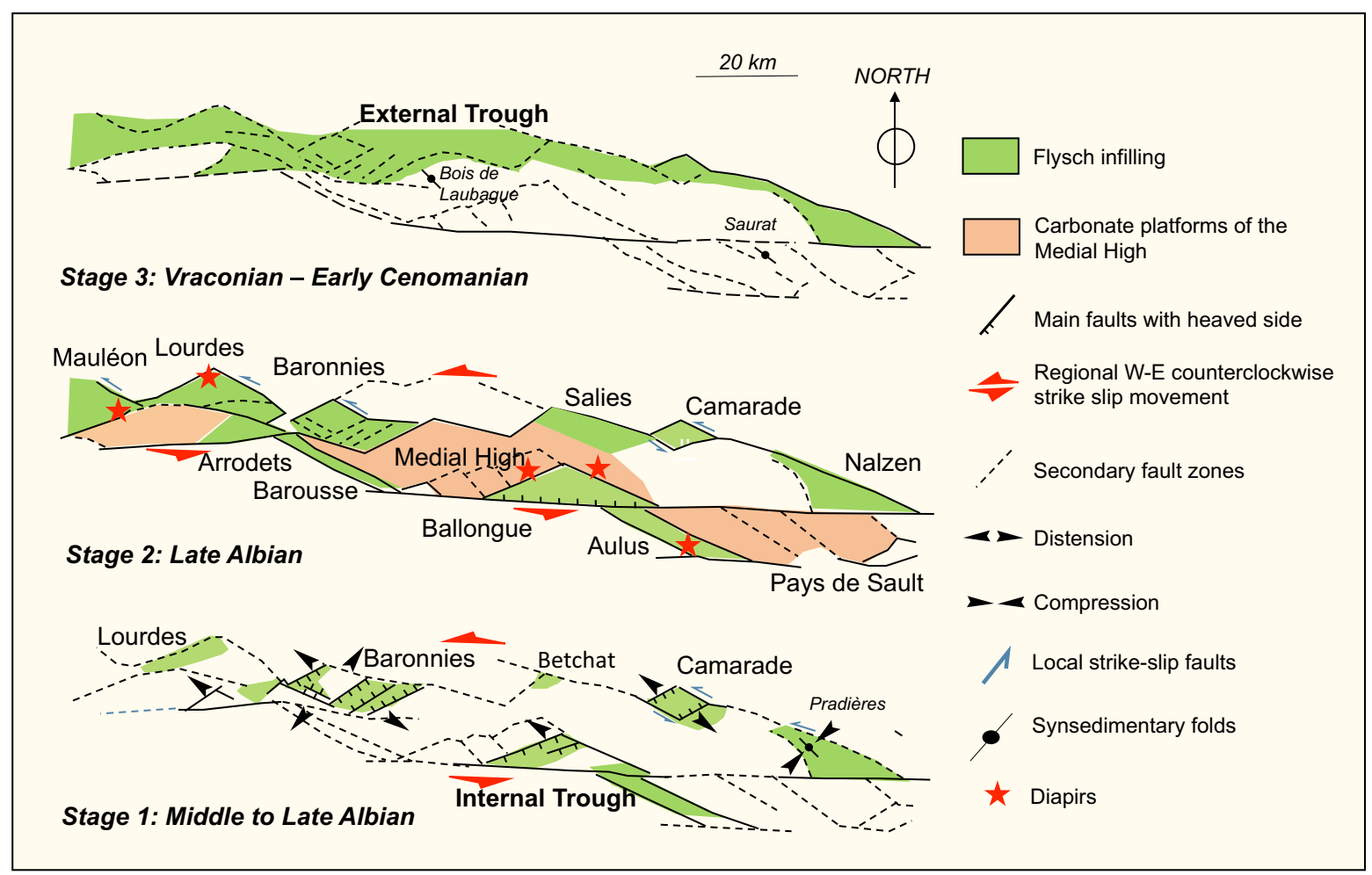

Fig 9. The three formation stages of the North Pyrenean Flysch Basins in the central Pyrenees (after Debroas, 1995).

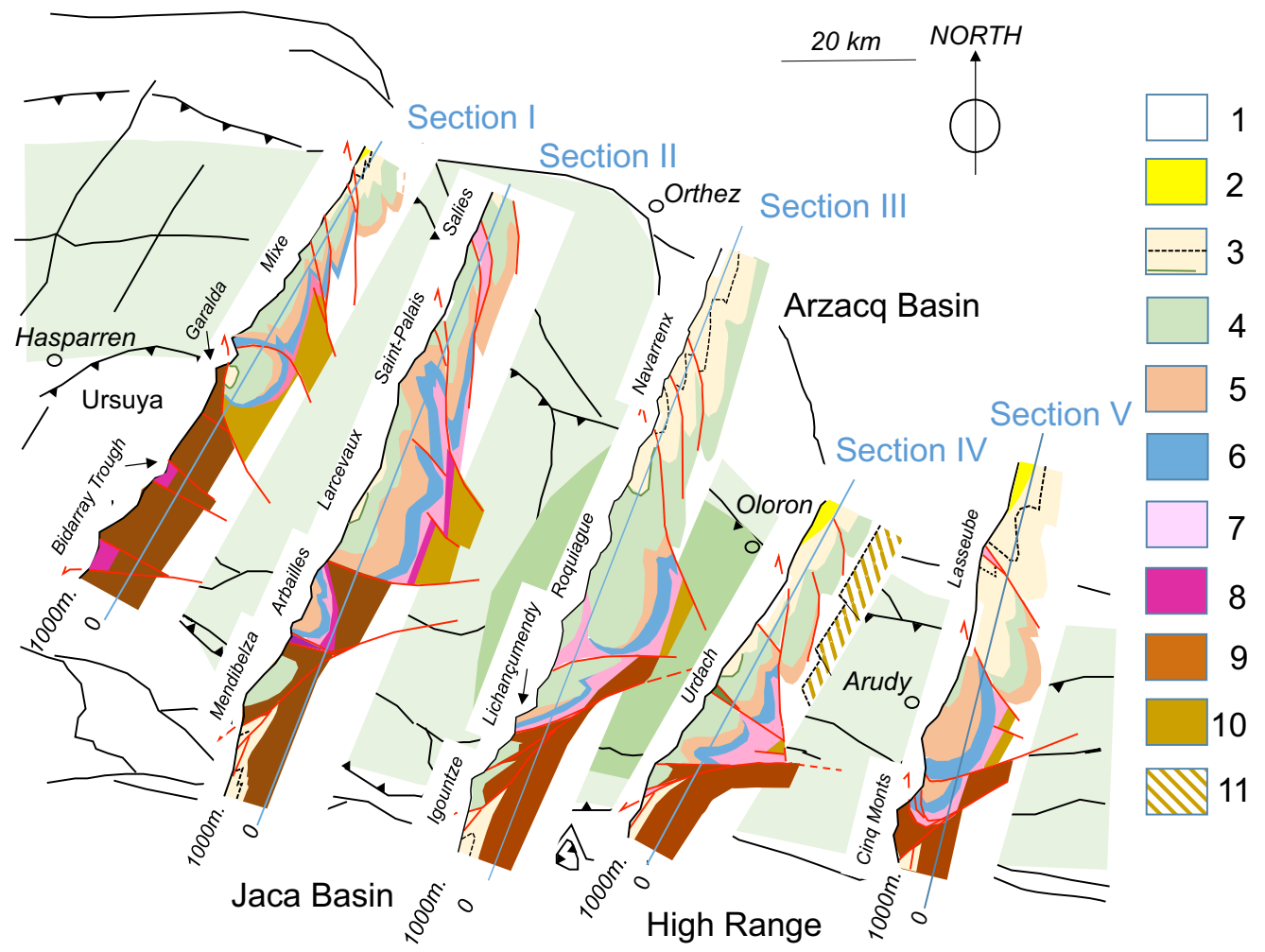

Fig. 10. Simplified seriate cross sections showing the geometry of the Tardets-Mauléon infilling and the hypothetic structural relationships between the old european and iberian margins of the Albian trough. 1: Quaternary; 2: Miocene; 3:Senonian to Eocene (black broken line: base of the Tertiary; green line: Turono-Coniacian megaturbidite); 4: Upper Albian-Turonian; 5: Aptian-Lower Albian; 6: Jurassic - Lower Cretaceous (ante Aptian); 7: Triassic; 8: Permian; 9: Palaeozoic (iberian margin); 10: Palaeozoic (european margin); 11: Grand Rieu ridge. 


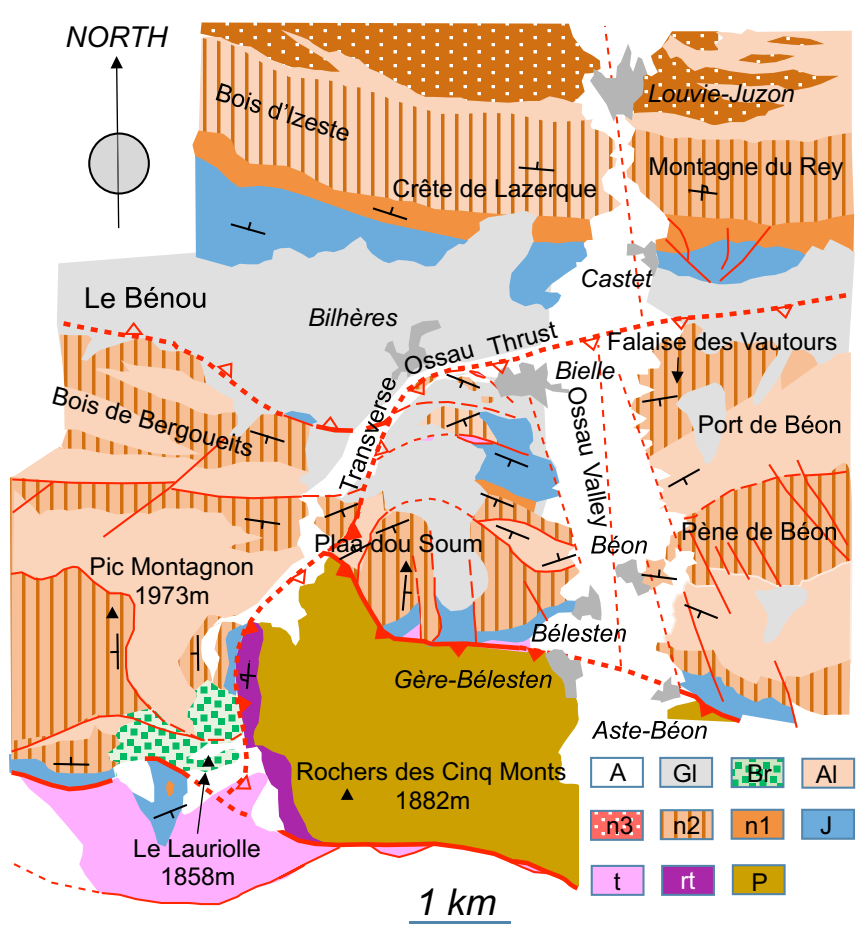

Fig. 11. Geological map of the Bielle area in the middle Ossau valley. A: Quaternary (alluvium); Gl: Quaternary (glacial tills); Br: undifferenciated Cretaceous (Lauriolle diapiric breccias); $\mathrm{Al}$ : Clansayesian (Uppermost Aptian)-Lower Albian (black spi ${ }^{2}$ cule marls); n3: Clansayesian (Uppermost Aptian)-Lower Albian (Arudy limestones); n2: Aptian (rudist-bearing limestones); n1: BarremoBedoulian (limestones with annelids and Deshayesites-bearing marls); J: undifferenciated Jurassic (limestones, dolostones and marls); T: Middle-Upper Triassic (shales, cellular dolomites and ophite); Pm: Permo-Triassic (quartzite-bearing conglomerates); P: undifferenciated Palaeozoic (Cinq Monts formation).

the Western Pyrenees and particularly in the considered Tardets-Mauléon Basin, this fault has no field reality. The southern part of the North Pyrenean Zone in fact interfingers with the northern part of the Axial Zone (High Primary Range) through the Bielle-Accous NW-SE oriented transverse zone (Canérot et al., 2004; Canérot, 2008, 2016).

\subsubsection{The SW-NE transverse faults}

Contemporaneous and closely related to the preceding WE faults, they are less developed and poorly represented superficially within the Albian infilling of the TardetsSorholus basin. Taking into account their SW-NE orientation and the sub-meridian orientation of the Africa Plate motion, these old Cretaceous normal faults suffered a dominant strikeslip motion during the Pyrenean compression phase. We observe a local left lateral movement along the eastern Ossau fault and a dextral one westward of the Barlanès fault zone (Urdach Pass), related to the rhombic shape of the TardetsSorholus Albian basin (Fig. 6D). The dextral strike-slip is particularly obvious more to the west, along the Saint-JeanPied-de-Port fault that determined the development of the Ursuya and Orthez-Sainte-Suzanne thrusting structures (Figs. 4 and 7). This new interpretation, supported by sedimentological and structural evidences such as the inverted sequence of the Mid-Upper Cretaceous Bonloc north-dipping flysch (Fig. 4), leading to the contact between the Turono-Coniacian megaturbidite and the Ursuya CambroSilurian gneisses and granulites, allows us to consider that this contact is tectonic (Fig. 10, section 1) and not stratigraphic as indicated by the Iholdy map (Le Pochat et al., 1978) and most of the recent studies of the area (Jammes, 2009; Masini, 2011; Masini et al., 2012).

The transverse structures related to regional SW-NE strike slip affect the W-E dominant folds and thrusts and modify their axial direction (Urdach, Saint-Palais). In such a scheme, the whole Mesozoic and Cenozoic infilling of the Mauléon Basin presents a fold and fault bundle structure with a general thrust tendency towards the SW in its eastern part and towards the NE in its western one, the main direction change occurring along the Barlanès and Saint-Jean-Pied-de-Port fault zones (Figs. 2, 4, 7 and 10).

\subsubsection{The transverse Ossau thrust fault}

In the southeastern part of the Mauléon Basin, the main strike E-W structures of the Chaînons Béarnais zone that thrust towards the south are crossed out by north verging folds with axis plunging toward the NW. This folding phase which was known long ago (Canérot, 1964) has been recently outlighted in the Ossau North Pyrenean Zone where it is interpreted as a north-verging D2 phase following the south-verging D1 phase (Dumont et al., 2015).

This second step of deformation generating NW vergent structures is in fact known in different points of the Western Pyrenees specially to the west of Adour Valley. In the Lourdes area, along the Pibeste and Pic du Ger Bigorre massifs, this deformation phase generated a bundle of NE-SW oriented thrust faults and folds which characterize the Lugagnan Fault Zone (Canérot, 2008; Canérot et al., 2012). These structures are also well developed farther west, close to the here considered Ossau valley where they characterize the Transverse Ossau Thrust (Canérot, 2008). In this area, the transverse structure is represented by a curved NW-verging thrust fault (Figs. 4 and 11) not represented on the published local map (Castéras, 1970). In its southern part, the Cinq Monts Devonian, Carboniferous and Permo-Triassic folded formations overthrust the western Jurassic and Albo Aptian limestones, marls and diapiric breccias of the Montagnon and Lauriolle mountains (Majesté-Menjoulas, 1979) along a $\mathrm{N}-\mathrm{S}$ oriented reverse fault. Then it reaches northeastward the Bielle village and the Castet mountain where the Albo-Aptian Port de Béon folded series faces the inverted Jurassic and Lower Cretaceous Montagne du Rey sequence. In this area, the Ossau thrust links to the south-verging Bénou Thrust before running eastward towards Ouzom valley. In the Bielle and Gere-Belesten western side of Ossau valley, the transverse thrust movement induces the cutting up of the Triassic, Jurassic and Lower Cretaceous overlapping series into five stacking slices facing the northwestern Sarrance-Bois de Bergoueits strike anticline (Fig. 11).

As mentioned by recent studies (Dumont et al., 2015), this transverse reworking of the folded structures involves other Béarn areas such as the western Ourdinse-Layens one, where the fold axes plunge towards the NW and the Arcizettes in the Eaux 
Chaudes eastern area. Following the Pyrenean Eocene main folding phase, it indicates a late (Oligocene?) change in the stress field of the African plate which moved northward and turned henceforth to northwest. This change is well represented on the southeastern border of the Mauléon Basin (Fig. 8D), locally highlighting the importance of the Cretaceous inheritance on the Tertiary structure of the Pyrenees.

\section{Conclusion}

The Mauleon Basin is a good example of a subsiding domain generated by the Upper Cretaceous widening of the Albo-Aptian Tardets-Sorholus pull-apart basin related to a N-S extension and a W-E sinistral conjugated strike-slip movement. This complex evolution induced the creation of transverse NE-SW oriented listric faults leading to the local (Urdach and probably Chabalgoïty) lherzolitic mantle exhumation.

This basin is located in a privileged situation within the North Pyrenean Cretaceous Flysch Trough between two opposed domains:

- the western Bilbao basin where dominant N-S extension generated two opposed, Iberian and European passive margins, separated by an axial zone showing an oceanic crust;

- the eastern small basins of the Central and Eastern Pyrenees where the dominant W-E sinistral strike-slip motion crossing NW-SE oriented fold structures led to transpression and prohibited in this case the generation of oceanic crust and mantle exhumation.

In the Tardets-Mauléon area, the structural Pyrenean framework has been deeply influenced by the inherited organization of the Cretaceous basin through tectonic inversion processes. Indeed, the W-E strike slip and then normal faults have been converted into reverse or thrust faults. The transverse SW-NE oriented normal (listric) faults have been reactivated into dextral or sinistral strike-slip faults. Finally, on the eastern side of the basin, close to Ossau valley, one of these transverse structures has been converted into a NW-verging thrust fault.

The regional transverse cross-sections reveal fan shaped structures that indicate that the Tardets-Mauléon Cretaceous infilling was located at the boundary between two Pyrenean facing margins:

- the southern margin consisting of Iberian crust which outcrops in the Chaînons Béarnais area and shows dominant southward-verging thrusts and folds;

- the northern margin consisting of European crust, known mainly through seismic profiles and oil drillings, which displays a north-verging structural framework at the transition with the Arzacq Basin.

This structural interpretation leads to deny the field evidence of the classical "North Pyrenean transform fault" located for some authors along the axis of the sedimentary basin and for others between the North Pyrenean Zone and the Axial zone (High Primary Range). Following a recent study (Canérot, 2016), we propose that the whole Tardets-Mauléon
Basin corresponds to the suture zone between Europe and Iberia. In such a scheme, Iberia cannot be longer interpreted as a really independent plate. It better corresponds to a moving part of Europe which was cut into different blocks suffering internal diachronous rotational movements under the northward motion of Africa. This is in agreement with the scissorlike opening of the Gulf of Biscay and the eastward North Pyrenean Flysch trough.

The Cretaceous and Tertiary history of the TardetsMauléon Basin shows that contrary to the commonly accepted interpretations that remain conceptual and do not fit very well field reality, the Pyrenees can no longer be defined as an interplate belt resulting from the collision between the European and Iberian plates. They better correspond to the Latest Cretaceous and Eocene structural inversion of the en échelon flysch pull-apart basins located towards the end of the Early Cretaceous along the future North Pyrenean Zone.

Acknowledgements. The main field data gathered in this paper highlight a long cooperation with E.-J. Debroas and M. Bilotte who are warmly acknowledged. Thanks are also given to $\mathrm{M}$. Grégoire, Ph. Olivier, L. Jolivet (editor-in-Chief of the B.S.G. F. Earth Sciences Bulletin) and to an anonymous referee whose comments largely improved the initial manuscript.

\section{References}

Azambre B, Sagon J-P., Debroas E-J. 1991. Le métamorphisme crétacé du fossé des Baronnies (Hautes-Pyrénées, France), témoin des anomalies thermiques de la zone transformante nordpyrénéenne. Comptes Rendus de l'Académie des Sciences, Paris 313 (2): 1179-1184.

Barbier F, Keen C, Potter P. 1986. Structure profonde de la marge Nord Gascogne. Implications sur le mécanisme de rifting et de formation de la marge continentale. Bulletin des Centres de Recherche Exploration/Production Elf Aquitaine 10: 105-121.

Boillot G. 1984. Le Golfe de Gascogne et les Pyrénées. In: Les marges continentales actuelles et fossiles autour de la France. Paris: Masson éd., pp. 7-73.

Boirie JM. 1981. Étude sédimentologique des Poudingues de Mendibelza (Pyrénées-Atlantiques), Thèse $3^{\mathrm{e}}$ Cycle, Toulouse, $114 \mathrm{p}$.

Boirie JM, Souquet P. 1982. Les poudingues de Mendibelza: dépôts de cônes sous-marins du rift albien des Pyrénées. Bull. Centres Recherches Exploration/Production Elf Aquitaine 6 (2): 405-435.

Bois C, Gariel O, Lefort JP, Rolet J, Brunet MF, Masse P, et al. 1997. Geologic contribution of the Bay of Biscay deep seismic survey: a summary of the main scientific results, a discussion of the open questions and suggestions for further investigations. Mémoires de la Société géologique de France 171: 193-209.

Canérot J. 1964. Contribution à l'étude géologique des chaînons nordpyrénéens compris entre les vallées d'Aspe et d'Ossau (B.P.), Thèse $3^{\mathrm{e}}$ Cycle, Université de Toulouse, $200 \mathrm{p}$.

Canérot J. 1988. Manifestations de l'halocinèse dans les chaînons béarnais (Zone Nord-Pyrénéenne) au Crétacé inférieur. Comptes Rendus de l'Académie des Sciences, Paris 306 (2): 1099-1102.

Canérot J. 2008. Les Pyrénées : histoire géologique et itinéraires de découverte. Biarritz : Atlantica/BRGM éds., 2 tomes, 646 p.

Canérot J. 2016. The Iberian plate: myth or reality? Boletin Geologico y Minero de España 127 (2/3): 557-568.

Canérot J, Delavaux J-F. 1986. Tectonique et sédimentation sur la marge nord-ibérique des chaînons béarnais (Pyrénées 
basco-béarnaises). Remise en question de la signification des lherzolites du sommet de Saraillé. C.R. Acad. Sci. Paris 302: 951-956.

Canérot J, Majesté-Menjoulas Cl, Ternet Y. 2004. Nouvelle interprétation structurale de la " faille nord-pyrénéenne » en vallée d'Aspe (Pyrénées-Atlantiques). Remise en question d'un plutonisme ophitique danien dans le secteur de Bedous. Comptes Rendus Geoscience 336: 135-142.

Canérot J, Debroas EJ, Azambre B, Largier G, Magnin B, Mouillac J, et al. 2012. Société géologique de France, Réunion Extraordinaire «Pyrénées », livret-guide d'excursion dans les Pyrénées centrales et occidentales, $133 \mathrm{p}$ (déposé à la Soc. géol. France).

Castéras M. 1970. Carte géologique de la France à 1/50 000, feuille $\mathrm{n}^{\circ} \mathrm{XV}-46$, Oloron-Sainte-Marie, avec notice explicative. Orléans : BRGM éd., 19 p.

Castéras M. 1971. Carte géologique de la France à 1/50 000, feuille $\mathrm{n}^{\circ} \mathrm{XIV}-46$, Tardets-Sorholus, avec notice explicative. Orléans : BRGM éd., $20 \mathrm{p}$.

Choukroune P, Mattauer M. 1978. Tectonique des plaques et Pyrénées : sur le fonctionnement de la faille transformante nordpyrénéenne; comparaisons avec des modèles actuels. Bulletin de la Société géologique de France 7: 689-700.

Claude D. 1990. Étude stratigraphique, sédimentologique et structurale des dépôts mésozoïques au nord du massif du Labourd, rôle de la faille de Pampelune, Thèse de Doctorat, Bordeaux 3, $437 \mathrm{p}$.

Clerc C, Lagabrielle Y, Neumaier M, Reynaud JY, De Saint-Blanquat M. 2012. Exhumation of subcontinental mantle rocks: evidence from ultramafic-bearing clastic deposits nearby the Lherz peridotite body, French Pyrenees. Bulletin de la Société géologique de France 183 (5): 443-459.

Colchen M, Ternet Y, Debroas EJ. 1997. Carte géologique de la France à $1 / 50000$, feuille $n^{\circ} 1086$, Aulus-les-Bains, avec notice explicative. Orléans: BRGM éd., 146 p.

Corre B, Lagabrielle Y, Labaume P, Fourcade S, Clerc C, Ballevre M. 2016. Deformation associated with mantle exhumation in a distal, hot passive margin environment: new constraints from the Saraillé Massif (Chaînons Béarnais, North-Pyrenean Zone). Comptes Rendus Geoscience 348: 279-289. Available from https://doi. org/10.1016.j.crte.2015.11.007.

Debroas E-J. 1985. Géométrie et position structurale des fossés albiens nord-pyrénéens : l'exemple des Pyrénées centrales, «sédimentation et tectonique», Ass. Sédim. Français-Société géologique de France, Paris, 1984. Strata Toulouse 1 (2): 99-106.

Debroas E-J. 1987. Modèle de bassin triangulaire à l'intersection de décrochements divergents pour le fossé albo-cénomanien de la Ballongue (zone nord-pyrénéenne, France). Bulletin de la Société géologique de France 8, III (5): 887-898.

Debroas E-J. 1990. Le Flysch Noir albo-cénomanien témoin de la structuration albienne à sénonienne de la zone nord-pyrénéenne en Bigorre (Hautes-Pyrénées, France). Bulletin de la Société géologique de France 8, VI (2): 273-285.

Debroas E-J. 2003. Le bassin du Flysch noir albo-cénomanien dans les Pyrénées centrales : un rift à ouverture triphasée, en transtension sénestre, d'extension décroissante vers l'Est et d'amplitude pluridécakilométrique. In: «Bassins crétacés de France et d'Europe occidentale ", séance spécialisée SGF, AGBP, APF, ASF, CFS, Paris (en dépôt à la Société géologique de France).

Debroas E-J. 2013. Sedimentological, stratigraphic and structural evidence for tectonic setting of the albo-cenomanian Flysch Noir basin in the central Pyrenees. Colloque ANR PYRAMID, Bonascre. Available from http://anr-pyramid.crpg.cnrs-nancy.fr/ IMG/pdf/Debroas-abs.pdf; http://anr-pyramid.crpg.cnrs-nancy.fr/ IMG/pdf/Debroas.pdf.
Debroas EJ, Azambre B. 2012. Des brèches au lherzolites : la mise en place des lherzolites dans les fossés du Flysch Noir albocénomanien de la Ballongue et d'Aulus (Zone Nord-Pyrénéenne, Ariège), livret-guide d'excursion AGSO (en dépôt à la Soc. géol. France), 119 p. Disponible sur http://geolfrance.brgm.fr/brechesaux-lherzolites-mise-en-place-lherzolites-fosses-flysch-noir-albocenomanien-ballongue.

Debroas EJ, Souquet P. 1976. Sédimentogenèse et position structurale des flyschs crétacés du versant nord des Pyrénées centrales. Journées de l'Association des Géologues du Sud-Ouest, Toulouse, 1974. Bull BRGM 1 (4): 305-320.

Debroas EJ, Canerot J, Bilotte M. 2010. Les brèches d'Urdach, témoins de l'exhumation du manteau pyrénéen dans un escarpement de faille vraconien-cénomanien inférieur (Zone NordPyrénéenne, Pyrénées-Atlantiques, France). Géologie de la France 2: 53-63. Disponible sur http://geolfrance.brgm.fr/breches-dur dach-temoins-lexhumation-manteau-pyreneen-escarpement-faillevraconien-cenomanien.

Debroas EJ, Canerot J, Bilotte M. 2013. Comment on "Exhumation of subcontinental mantle rocks: evidence from ultramafic-bearing clastic deposits nearby the Lherz peridotite body, French Pyrenees" by Clerc C, et al. Bulletin de la Société géologique de France 184 (6): 621-629.

Dumont Th, Replumaz A, Roumejon S, Briais A, Rigo A, Bouillin JP. 2015. Microseismicity of the Béarn range: reactivation of inversion and collision structures at the northern edge of the Iberian plate. Tectonics 34. DOI: 10.1002/2014TC003816.

Ferrer O, Roca E, Benjumea B, Muñoz JA, Ellouz N, Marcony Team. 2008. The deep seismic reflexion MARCONI-3 profile: role of extensional mesozoic structures during the pyrenean contractional deformation at the eastern part of the Bay of Biscay. Marine and Petroleum Geology. DOI: 10.1016/j.marpetgeo.2008.06.002.

Flament JM. 1985. L'exploration pétrolière au sud du Front NordPyrénéen. Bilan et perspectives. Annales des Mines 3-4: 43-49.

Gong Z, Langereis CG, Mullender TAT. 2008. The rotation of Iberia during the Aptian and the openning of the Bay of Biscay. Earth and Planetary Science Letters (2008). DOI: 10.1016/j. eps1.2008.06.016.

James V, Canérot J. 1999. Diapirisme et structuration post-triasique des Pyrénées occidentales et de l'Aquitaine méridionale (France). Eclogae Geologicae Helvetiae 92: 63-72.

Jammes S. 2009. Processus d'amincissement crustal en contexte transtensif: l'exemple du Golfe de Gascogne et des Pyrénées basques, Thèse Doctorat, Univ. Strasbourg, 280 p.

Jammes S, Manatschal G, Lavier L, Masini E. 2009. Tectonosedimentary evolution related to extreme crustal thinning ahead of a propagating ocean: the example of the western Pyrenees. Tectonics. DOI: 10.1029/2008TC002406.

Lagabrielle Y, Bodinier JL. 2008. Submarine reworking of exhumed continental mantle rocks: field evidence from the Lherz peridotites, French Pyrenees. Terra Nova 20 (1): 11-21. DOI: 10.1111/ J.1365-3121.2007.000781.

Lagabrielle Y, Labaume P, De Saint-Blanquat M. 2010. Mantle exhumation, crustal denudation and gravity tectonics during Cretaceous rifting in the Pyrenean realm (SW Europe): insights from the geological setting of the lherzolite bodies. Tectonics 29: TC4012. Available from https://doi.org/10.1029/2009TC002588.

Lagabrielle Y, Clerc C, Vauchez A, Lahfid A, Labaume P, Azambre B, et al. 2016. Very high geothermal gradient during mantle exhumation recorded in mylonitic marbles and carbonate beccias from a Mesozoic Pyrenean palaeomargin (Lherz area, North Pyrenean Zone, France). Comptes Rendus Geoscience 348: 290 300. Available from https://doi.org/10.1016/j.crte.2015.11.004. 
Le Pichon X, Sibuet JC. 1971. Western extension of boundary between European and Iberian plates during the Pyrenean orogeny. Earth and Planetary Sciences and Letters 12: 83-88.

Le Pichon X, Bonnin J, Sibuet JC. 1970. La faille nord-pyrénéenne : faille transformante liée à l'ouverture du golfe de Gascogne. Comptes Rendus de l'Académie des Sciences, Paris 271: 19411944.

Le Pochat G, Lenguin M, Thibault Cl. 1976. Carte géologique de la France à 1/50000, feuille $n^{\circ}$ XIV-45, Mauléon-Licharre, avec notice explicative. Orléans : BRGM éd., $24 \mathrm{p}$.

Le Pochat G, Lenguin M, Napias J-Cl, Thibaut Cl, Roger Ph, Bois J-P. 1978. Carte géologique de la France à $1 / 50$ 000, feuille $n^{\circ}$ XIII-46, Saint-Jean-Pied-de-Port, avec notice explicative. Orléans : BRGM éd., 41 p.

Majesté-Menjoulas Cl. 1979. Évolution alpine d'un segment de chaîne varisque : nappe de Gavarnie, chevauchement Cinq-MontsGentiane (Pyrénées centrales et occidentales), Thèse de Doctorat d'État, Toulouse, $343 \mathrm{p}$.

Masini E. 2011. L'évolution tecto-sédimentaire syn-rift des bassins de marge passive profonde: exemples du bassin de Samedan (Alpes centrales, Suisse) et du bassin de Mauléon (Pyrénées basques françaises), Thèse de Doctorat, Univ. Strasbourg, 205 p.

Masini E, Jammes S, Mouthereau F. 2012. The Mauleon Basin: a preserved hyper-extended rift basin? St-Martin-d'Arrossa: Pyrenees Workshop, $38 \mathrm{p}$.

Montadert L, Winnock E. 1971. L'histoire structurale du golfe de Gascogne. In: Histoire structurale du golfe de Gascogne. Paris : Technip éd., vol. VI, pp. 16-18.

Muñoz JA. 1992. Evolution of a continental collision belt: ECORSPyrenees crustal balanced cross-section. In: McClay KR, ed. Thrust tectonics. Dordrecht, Netherlands: Springer, pp. 235-246.

Olivet JL. 1996. La cinématique de la plaque ibérique. Bulletin des Centres de Recherche Exploration/Production Elf Aquitaine 20 (1): 131-195.

Pedreira D, Pulgar JA, Gallart J, Torne M. 2007. Three-dimensional gravity and magnetic modeling of crustal indentation and wedging in the western Pyrenees-Cantabrian Mountains. Journal of Geophysical Research 112: B12405. DOI: 10.1029/ 2007JB005021.

Puigdefabregas C, Souquet P. 1986. Tecto-sedimentary cycles and depositioal sequences of the Mesozoic and Tertiary from the Pyrenees. Tectonophysics, Amsterdam 129: 173-203.

Razin Ph. 1989. Évolution tecto-sédimentaire alpine des Pyrénées basques à l'ouest de la transformante de Pamplona (Province du Labourd), Thèse Doctorat Université de Bordeaux III, Bordeaux, $464 \mathrm{p}$.

Saint-Blanquat M, De Bajolet F, Grand'homme A, Proietti A, Zanti M, Boutin A, et al. 2016. Cretaceous mantle exhumation in the central Pyrenees: new constraints from the peridotites in eastern
Ariège (North Pyrenean zone, France). Comptes Rendus Geoscience 348: 268-278. Available from https://doi.org/10.1016/j. crte.2015.12.003.

Serrano O, Delmas J, Hanot F, Vially R, Herbin J-P., Houel P, et al. 2006. Le Bassin d'Aquitaine: valorisation des données sismiques, cartographie structurale et potentiel pétrolier. Orléans : BRGMIFP éd., 245 p.

Sibuet JC, Pautot G, Le Pichon X. 1971. Interprétation structurale du golfe de Gascogne à partir des profils de sismique. In: histoire structurale du golfe de Gascogne. Paris : Éditions Technip, vol. 22, pp. VI.10.1-32.

Sibuet JC, Srivastava SP, Spakman W. 2004. Pyrenean orogeny and plate tectonics. Journal of Geophysical Research 109: B08104. DOI: $10.1029 / 2003 J B 002514$.

Souquet P, Peybernes B, Bilotte M, Debroas EJ. 1977. La chaîne alpine des Pyrénées. Géologie Alpine, Grenoble 53 (2): 193-216.

Souquet P, Debroas EJ, Boirie JM, Pons Ph, Fixari G, Dol J, et al. 1985. Le groupe du Flysch noir (albo-cénomanien) dans les Pyrénées. Bulletin des Centres de Recherche Exploration/Production Elf-Aquitaine, Pau 9 (1): 183-252.

Srivastava SP, Roest WR, Kovacs LC, Okay G, Levesque S, Verhoef $\mathrm{J}$, et al. 1990a. Motion of Iberia since the Late Jurassic: results from detailed aeromagnetic measurements in the Newfoundland basin. Tectonophysics 184: 229-260.

Srivastava SP, Roest WR, Kovacs LC, Okay G, Levesque S, Verhoef J, et al. 1990b. Jumping plate boundary between Eurasia and Africa. Nature 344: 756-759.

Stampfli GM. 2011. Alpes : tectonique des plaques et géodynamique. In: La chaîne alpine. Perspectives helvétiques. Géochronique 117, Dossier: 18-21.

Teixell A. 1998. Crustal structure and orogenic material budget in the west central Pyrenees. Tectonics 17: 395-406. DOI: 10.1029/ 98TC00561.

Teixell A, Labaume P, Lagabrielle Y. 2016. The crustal evolution of the west-central Pyrenees revisited: inferences from a new kinematic scenario. Comptes Rendus Geoscience 348: 257-267. Available from https://doi.org/10.1016/j.crte.2015.10.010.

Ternet Y. 1965. Étude du synclinal complexe des Eaux-Chaudes (Basses-Pyrénées), Thèse Doctorat $3^{\mathrm{e}}$ Cycle, Toulouse, $166 \mathrm{p}$.

Tugend J, Manatschal G, Kusznir NJ, Masini E, Mohn G, Thinon I. 2014. Formation and deformation of hyper-extended rift systems: insights from rift domain mapping in the Bay of Biscay-Pyrenees. Tectonics 33: 1239-1276. DOI: 10.1002/2014TC003529.

Verges J, Millan H, Roca E, Muñoz JA, Marzo M, Cires J, et al. 1995. Eastern Pyrenees and related foreland basins-Precollisional, syncollisional and postcollisional crustal-scale cross sections. Marine and Petroleum Geology 12: 903-915.

Vissers RLM, Meijer PTh. 2012. Mesozoic rotation of Iberia: subduction in the Pyrenees? Earth-Science Reviews 110: 93-110.

Cite this article as: Canérot J. 2017. The pull apart-type Tardets-Mauléon Basin, a key to understand the formation of the Pyrenees, Bull. Soc. géol. Fr. 188: 35. 